\title{
Original article \\ Influence of creatine supplementation on indicators of glucose metabolism in skeletal muscle of exercised rats
}

\author{
Michel Barbosa de Araújo \\ São Paulo State University at Rio Claro, Brazil \\ Roberto Carlos Vieira Junior \\ Federal University of Mato Grosso, Brazil \\ Leandro Pereira de Moura \\ Marcelo Costa Junior \\ Rodrigo Augusto Dalia \\ Amanda Christine da Silva Sponton \\ Carla Ribeiro \\ Maria Alice Rostom de Mello \\ São Paulo State University at Rio Claro, Brazil
}

\begin{abstract}
The purpose of this study was to evaluate the effect of creatine supplementation in the diet on indicators of glucose metabolism in skeletal muscle of exercised rats. Forty Wistar adult rats were distributed into four groups for eight weeks: 1) Control: sedentary rats that received balanced diet; 2) Creatine control: sedentary rats that received supplementation of $2 \%$ creatine in the balanced diet; 3 ) Trained: rats that ran on a treadmill at the Maximal Lactate Steady State and received balanced diet; and 4) Supplemented-trained: rats that ran on a treadmill at the Maximal Lactate Steady State and received creatine supplementation (2\%) in the balanced diet. The hydric intake increased and the body weight gain decreased in the supplemented-trained group. In the soleus muscle, the glucose oxidation increased in both supplemented groups. The production of lactate and glycemia during glucose tolerance test decreased in the supplemented-trained group. Creatine supplementation in conjunction with exercise training improved muscular glycidic metabolism of rats.
\end{abstract}

Keywords: somatic index, glucose tolerance, physical activity

Resumo- "Influência da suplementação com creatina em indicadores de metabolismo da glucose no músculo esquelético de ratos exercitados." O objetivo deste estudo foi avaliar o efeito da suplementação de creatina na dieta sobre indicadores do metabolismo glicídico musculoesquelético de ratos exercitados. Quarenta ratos Wistar adultos foram divididos em quatro grupos por oito semanas: Controle: receberam dieta balanceada, mantidos sedentários; Controle Creatina: receberam suplementação de creatina (2\%) na dieta balanceada, mantidos sedentários; Treinado: correram em esteira na intensidade da máxima fase estável de lactato e receberam a dieta balanceada e grupo Treinado Suplementado: correram em esteira na intensidade da máxima fase estável de lactato e receberam suplementação de creatina (2\%) na dieta balanceada. A ingestão hídrica aumentou e o ganho de massa corporal reduziu no grupo treinado e suplementado. No músculo sóleo, a oxidação de glicose aumentou em ambos os grupos suplementados. A produção de lactato e a glicemia durante teste de tolerância à glicose diminuíram no grupo treinado e suplementado. A suplementação com creatina em conjunto com treinamento físico melhorou metabolismo de glicídico muscular dos ratos.

Palavras-chaves: índice somático, tolerância à glicose, atividade física

Resumen- "Influencia de la suplementación con creatina sobre indicadores del metabolismo de la glucosa en el músculo esquelético de ratas ejercitadas." El objetivo de este estudio fue evaluar el efecto de la suplementación con creatina en la dieta sobre indicadores del metabolismo de glucosa en el músculo esquelético en ratones ejercitados. Cuarenta ratas macho adultas Wistar se dividieron en cuatro grupos de ocho semanas: Control: recibieron dieta equilibrada, mantenido sedentaria; Control Complementado: La suplementación con creatina recibido (2\%) en la dieta equilibrada, sedentaria mantenido; Trained: corriendo en una cinta en la intensidad de máximo estado estable de lactato y recibió el grupo de dieta equilibrada y grupo Treinado Complementado: corriendo sobre una cinta rodante a una intensidad máxima de lactato estable y recibieron la suplementación con creatina (2\%) en una 
dieta equilibrada. El consumo de agua aumenta y reducción de la ganancia de peso corporal en la formación y complementado. En el músculo sóleo, la oxidación de la glucosa aumentó en ambos grupos suplementados. La producción de los niveles de lactato y de glucosa durante la prueba de tolerancia a la glucosa disminuida en la formación y complementado. La suplementación con creatina en conjunto con el entrenamiento físico mejora el metabolismo de la glucosa en el músculo de los ratones.

Palabras claves: índice somático, tolerancia a la glucosa, la actividad física

\section{Introduction}

Creatine is a supplement that has generated interest in sports, as $90 \%$ of the creatine in the body is stored in skeletal muscle. In skeletal muscle, creatine is present in the phosphorylated form, in conjunction with ATP, and serves as an energetic reserve that is essential for contraction (Williams et al., 2000; Araújo et al., 2009). Additional evidence suggests that this nutrient is capable of improving power and muscle strength and contributes to hypertrophy and lean mass gain (Bembem and Lamont, 2005; Hofman et al., 2006).

Creatine may influence glucose homeostasis in skeletal muscle (Freire et al., 2008; Gulano et al., 2008). The metabolic profile and energy homeostasis of muscle cells vary with changes in their activity level and supply of energy substrates. Previous studies have reported increased rates of insulin secretion (Souza et al., 2006), increased expression of GLUT-4 receptors (Op'Teijnde et al., 2001; Souza et al., 2006) and increased intramuscular glycogen concentration after supplementation with creatine (Young et al., 2002). Although it is believed that creatine has a hypoglycemic effect, several authors failed to confirm hyperinsulinemia after the ingestion of creatine (Newman et al., 2003; Freire et al., 2008). With regard to the sporting environment, the literature suggests that creatine supplementation alters glucose metabolism. In light of the similar effects of aerobic training on glucose metabolism we speculated that creatine supplementation accompanied by aerobic training could improve the glycidic profile, which would be important to several pathologies, including insulin resistance, glucose intolerance, diabetes mellitus and obesity, in individuals with cardiovascular disease.

As more studies are needed to clarify the true effects of creatine supplementation on glucose homeostasis, our hypothesis is that creatine supplementation may increase the glycemic index. Thus, the purpose of this study was to evaluate the effect of dietary creatine supplementation on the indicators of glucose metabolism in the skeletal muscle of exercised rats.

\section{Method}

\section{Animals and experimentation}

Forty male Wistar rats (90 days old) were selected and received water and food ad libitum. The rats were housed in collective cages made of polyethylene ( 5 animals per cage), measuring 37.0 × $31.0 \times 16.0 \mathrm{~cm}$, under controlled temperature conditions $\left(22^{\circ} \mathrm{C}\right)$ and a $12 \mathrm{~h} \mathrm{light/dark} \mathrm{cycle.}$ All experiments involving animals were approved by the Ethics Committee on Animal Experimentation at the University of Taubaté - UNITAU (register CEEA / UNITAU $\mathrm{n}^{\circ}$ 018/08).

Exercise training and creatine supplementation lasted eight weeks, and the animals were distributed into four groups: 1) Control (C): sedentary rats that received a balanced diet; 2) Creatine control ( $\mathrm{CCr}$ ): sedentary rats that received a balanced diet supplemented with $2 \%$ creatine; 3 ) Trained (T): rats that were submitted to a training protocol and received a balanced diet, and 4) Trained Creatine (TCr): rats that were submitted to a training protocol and received a balanced diet supplemented with $2 \%$ creatine.

\section{Supplementation, registration of body weight and food/water intake}

The animals in the groups supplemented with creatine (CCr and $\mathrm{TCr}$ ) received a balanced and isocaloric diet AIN93M (Reeves et al., 1993), with $2 \%$ or $13 \%$ monohydrate creatine (All Chemistry, São Paulo, SP, Brazil).

According to Hutman et al. (1996) and Vandenberghe et al. (1997), creatine supplementation must be offered in two phases when the aim is to promote an overload of this substrate in the organism. These phases consisted of a loading phase followed by a maintenance phase. In the loading phase, the diet was supplemented with $13 \%$ creatine for seven days, and in the maintenance phase, the diet was supplemented with $2 \%$ creatine for the rest of the experiment (55 days). Of note, the animals received creatine through their diet seven days a week for the eight weeks of the experiment. The animals from groups $\mathrm{C}$ and $\mathrm{T}$ received a balanced isocaloric diet, AIN-93M (Reeves et al., 1993), without the addition of creatine. The animals from Creatine groups received the same diet changing part of cornstarch to creatine. The detailed composition of the diet is described in Table 1.

During the experimental period, body weight and food and water intake were monitored weekly. The results of the dietary and hydric intakes were analyzed by calculating the area under the intake curves during the experiment using the trapezoidal method (Mathews et al., 1990).

\section{Protocol of physical activity}


Table 1. Diet composition.

\begin{tabular}{|c|c|c|c|}
\hline Components & $\begin{array}{c}\text { AIN - 93M* } \\
\left(g \_k g-1\right)\end{array}$ & $\begin{array}{c}\text { Addition of } 2 \% \\
\text { creatine** } \\
\left(\mathrm{g} \_\mathrm{kg}-1\right)\end{array}$ & $\begin{array}{c}\text { Addition of } 13 \% \\
\text { creatine**** } \\
\left(\mathrm{g} \_\mathrm{kg}-1\right)\end{array}$ \\
\hline Creatine & 0.0 & 20.0 & 130.0 \\
\hline Cornstarch & 465.7 & 444.7 & 335.7 \\
\hline Casein ( $85 \%$ protein) & 140.0 & 140.0 & 140.0 \\
\hline Dextrin & 155.0 & 155.0 & 155.0 \\
\hline Sucrose & 100.0 & 100.0 & 100.0 \\
\hline Soybean Oil & 40.0 & 40.0 & 40.0 \\
\hline Fiber & 50.0 & 50.0 & 50.0 \\
\hline Mineral mix & 35.0 & 35.0 & 35.0 \\
\hline Vitamin mix & 10.0 & 10.0 & 10.0 \\
\hline L-cystine & 1.8 & 1.8 & 1.8 \\
\hline Choline bitartrate & 2.5 & 2.5 & 2.5 \\
\hline $\mathrm{Kcal} / \mathrm{Kg}$ & $3.802,77$ & $3.802,77$ & $3.802,77$ \\
\hline
\end{tabular}

The rats in the trained groups performed exercise on a treadmill at an intensity equivalent to the maximal lactate steady state (MLSS). To determine the MLSS, an exercise series of 25 minutes racing with rectangular intensity was performed on a treadmill at different speeds $(15,20,25$ and $30 \mathrm{~m} / \mathrm{min}$ velocities), with 48 hours between each series. Blood samples from a small cut at the end of the tail $(25 \mu \mathrm{L})$ were collected every five minute to measure the lactate levels. A single incision made before beginning the exercise series was sufficient to collect all samples. The blood lactate concentration corresponding to the MLSS was taken at the highest speed where there was no variation of blood lactate greater than $1.0 \mathrm{mmol} / \mathrm{L}$ between 10 and $25 \mathrm{~min}$ of exercise (Manchado et al., 2005; Araújo et al., 2011). The blood lactate concentration was determined by an enzymatic method (Hill et al., 1924).

After the MLSS was determined, the animals ran on a treadmill at their MLSS intensities for 40 minutes/day for five days/week.

\section{Oral Glucose Tolerance Test - OGTT}

At 150 days old, an OGTT was performed on the animals after 12 hours of fasting. An initial blood sample was taken through a small cut at the end of the tail of each animal. Then, a glucose solution (80\%) was administered to each animal through a polyethylene gastric catheter at a dose of $2 \mathrm{~g} / \mathrm{kg}$ body weight. Blood samples were collected after 30 ,
60 and 120 min with heparinized capillaries $(25 \mu \mathrm{L})$ to determine the glucose concentration. A single incision was sufficient to collect all samples. The blood glucose concentrations were determined by the glucose oxidase method (Nogueira et al., 1990) and insulin was determined using a radioimmunoassay (Hebert et al., 1965). The results were analyzed by calculating the area under the glucose curve during the test using the trapezoidal method (Mathews et al., 1990) and the software ORIGIN 6.0 (2000).

\section{Indicators of muscular glycidic metabolism: oxidation and glucose uptake, glycogen synthesis and lactate production by the soleus muscle}

At the end of the experiment, when the rats were fed and rested, they were exsanguinated after being anesthetized with carbon dioxide. At the time of euthanasia, the right soleus muscle was excised to measure the indicators of muscular glycidic metabolism (oxidation and glucose uptake, synthesis and concentration of glycogen and production of lactate). The right soleus muscle was isolated with minimal injury, and longitudinal slices weighing between 25 and 35 $\mathrm{mg}$ were placed in $20 \mathrm{ml}$ siliconized scintillation vials containing $1.5 \mathrm{ml}$ of Krebs-Ringer bicarbonate buffer. The vials were closed with rubber covers, sealed with plastic rings and subjected to 30 minutes of preincubation while stirred in a Dubnoff bath at $60 \mathrm{rpm}$ and continuously gassed with $\mathrm{O}_{2} / \mathrm{CO}_{2}(95 \% / 5 \%)$. After the preincubation period, the 
muscular slices were transferred to new scintillation vials that had interior tubes in a shell form with a straight rod that was approximately three $\mathrm{cm}$ long inserted into the rubber cover of the outer vial. Each outer vial contained $1.5 \mathrm{~mL}$ Krebs-Ringer bicarbonate buffer, and each inner vial contained $700 \mathrm{ml}$ of hiamina10x. After 1 minute of incubation in this system, including gassing during the first 15 minutes, $100 \mathrm{ml}$ of trichloroacetic acid (TCA) $25 \%$ was added to the outer vial to release $\mathrm{CO}_{2}$. This solution was kept in the system for three hours with the slice of muscle beyond the reach of the solution with TCA. After this time, $200 \mathrm{ml}$ of the liquid contained in the outer vial was withdrawn to determine the amount of $\mathrm{CO}_{2}$ produced. The acidified incubation media contained in the outer vial was stored for the determination of the lactate levels, and the slice of muscle was immediately digested in $0.5 \mathrm{ml}$ of $\mathrm{KOH}$ for extraction (Sjorgreen et al., 1938) and muscular glycogen dosing (Dubois et al., 1956). The temperature during both preincubation and incubation was $37^{\circ} \mathrm{C}$. The Krebs-Ringer bicarbonate buffer, the base of the solutions used for preincubation and incubation, is composed of: $\mathrm{NaCl} 0.6 \%, \mathrm{NaHCO}_{3} 0.19 \%, 6.64$ mM HEPES, KCl $0.032 \%, \mathrm{CaCl}_{2} 1.14 \mathrm{nM}, \mathrm{KH}_{2} \mathrm{PO}_{4} 0.015 \%$ and $\mathrm{MgSO}_{4}$ $0.03 \%$. The prepared solution was gassed for 20 to 30 minutes in $\mathrm{O}_{2} / \mathrm{CO}_{2}(95 \% / 5 \%)$, and the $\mathrm{pH}$ was adjusted to 7.4 . During preincubation, Sodium pyruvate was added to achieve a final concentration of $5 \mathrm{mM}$. Glucose $(5.5 \mathrm{mM})$ containing $\left[\mathrm{U}-{ }^{14} \mathrm{C}\right]$ glucose $(0.25 \mathrm{mCi} / \mathrm{ml}),\left[{ }^{3} \mathrm{H}\right]$ 2-deoxyglucose $(2 \mathrm{DG}=0.5 \mathrm{mCi} /$ $\mathrm{ml})$ and insulin $(100 \mathrm{mUl} / \mathrm{ml})$ were then added. After the additions were performed, the $\mathrm{pH}$ was adjusted to 7.4 , and the solutions were transferred to vials that were sealed and equilibrated in a bath at $37^{\circ} \mathrm{C}$ under $\mathrm{O}_{2} / \mathrm{CO}_{2}(95 \% / 5 \%)$ for at least 15 minutes. Additional slices from the same muscle and of similar weights to those incubated were used to determine the concentration of the glycogen control. Glucose uptake was assessed using 2 DG as a marker, and the incorporation of ${ }^{14} \mathrm{C}$-glycogen (synthesis) was assessed by measuring the radioactivity of ${ }^{3} \mathrm{H}$ of $2 \mathrm{DG}{ }^{14} \mathrm{C}$-glucose using a beta particle counter. The radioactive lactate released into the incubation media was determined by separating the metabolites in an ionic exchange column (Dowex-2, Sigma). To estimate the oxidized glucose $\left(\mathrm{CO}_{2}\right.$ production), the radioactivity of the ${ }^{14} \mathrm{C}$ present in the liquid (hiamina) collected from the inner vial of the incubation system was determined (Nunes \& Mello, 2005).

\section{Statistical analyses}

Statistical analyses were performed with the aid of STATISTICA®, version 7.0. The analysis of the OGTT was performed using the ORIGIN 6.0 software. The data from the dietary and hydric intakes over the whole experiment were analyzed by calculating the area under the curve (AUC) using the trapezoidal method (Mathews et al., 1990). All experimental results were submitted to the Shapiro-Wilk normality test to establish the necessity of parametric statistics. The data were determined to have normal distributions. The results were expressed by the mean \pm standard deviation and were statistically analyzed by a twoway ANOVA followed by a Tukey HSD post-hoc test, when necessary. For all analyses, $p<0.05$ was considered significant.

\section{Results}

\section{Somatic indicators}

The data related to the body mass gain of the animals during the experiment are shown in Table 2. The animals of the trained groups ( $\mathrm{T}$ and $\mathrm{TCr}$ ) exhibited significantly reduced body mass throughout the experiment compared to the animals of the control groups ( $\mathrm{C}$ and $\mathrm{CCr}$ ). Table 2 shows the results of the area under the food intake curve of the rats during the study. The food intake of all of the animals remained stable throughout the experiment, with no significant differences among the groups. The animals of the $\mathrm{TCr}$ group showed higher hydric intakes compared to animals of the $\mathrm{C}$ group.

\section{Indicators of muscular metabolism}

Figure 1 contains the results concerning glucose metabolism in the soleus muscle at the end of the experiment. Glucose uptake, glycogen synthesis, and the glycogen concentration did not significantly differ among the assessed groups. Glucose oxidation was higher in the supplemented groups ( $\mathrm{TCr}$ and $\mathrm{CCr}$ ) compared to the non-supplemented groups ( $\mathrm{T}$ and $\mathrm{C})(p<0.05)$. Lactate production by the soleus muscle was reduced in the $\mathrm{TCr}$ group compared to the $\mathrm{CCr}$ group.

\section{Indicators of glucose tolerance and insulin sensitivity}

Figure 2 presents the results of the area under the glucose curve during the oral glucose tolerance test (OGTT) of the animals at the end of the experiment. The animals in the $\mathrm{TCr}$ group had a smaller area under the curve compared to animals in the control groups ( $\mathrm{C}$ and $\mathrm{CCr})$.

\section{Discussion}

The objective of this study was to evaluate the effect of dietary creatine supplementation on the indicators of the musculoskeletal glycidic metabolism of exercised rats. Some authors have reported that creatine supplementation may modify the use of energetic substrates, such as glucose and lactate, and possibly improve physical performance during extended exercises that preferentially use aerobic metabolism (Bembem et al., 2005; Souza et al. 2006; Khanna \& Manna, 2005).

The first analysis performed in the present study was with respect to the mass gain of the animals at the end of the 
Table 2. Body mass gain $(\mathrm{g})$, area under the curve of dietary intake ( $\mathrm{g} / 100 \mathrm{~g}$ rat $\mathrm{x} 4$ weeks) and area under the curve of hydric intake (ml/100 $\mathrm{g}$ rat $\mathrm{x}$ 4 weeks) of the animals at the end of the experiment.

\begin{tabular}{|c|c|c|c|c|}
\hline Parameters & $\mathrm{C}(10)$ & $\mathrm{CCr}(10)$ & $\mathrm{T}(10)$ & $\mathrm{TCr}(10)$ \\
\hline Mass Gain & $95,38 \pm 9,99$ & $101,32 \pm 8,61$ & $78 \pm 7,90 * \#$ & $53,60 \pm 6,36 * \#$ \\
\hline AUC - Dietary Intake & $253,68 \pm 2,80$ & $236,15 \pm 1,98$ & $216,65 \pm 1,47$ & $262,68 \pm 1,88$ \\
\hline AUC - Hydric Intake & $230,65 \pm 0,90$ & $292,84 \pm 3,40$ & $243,56 \pm 0,90$ & $334,07 \pm 3,60 *$ \\
\hline
\end{tabular}

Glucose Uptake

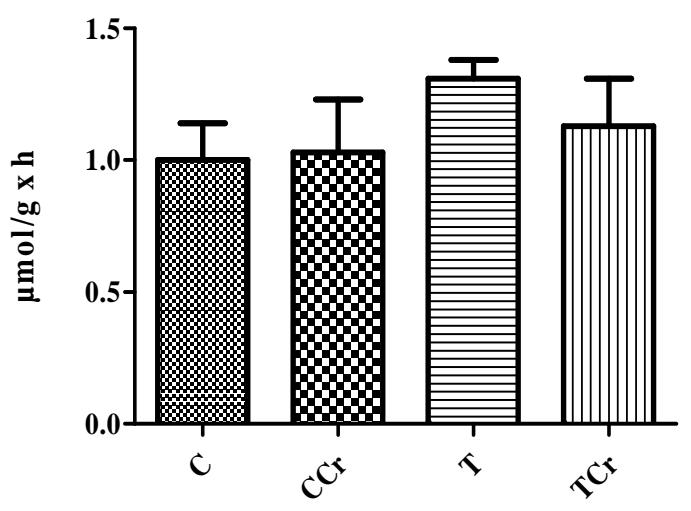

Lactate Production

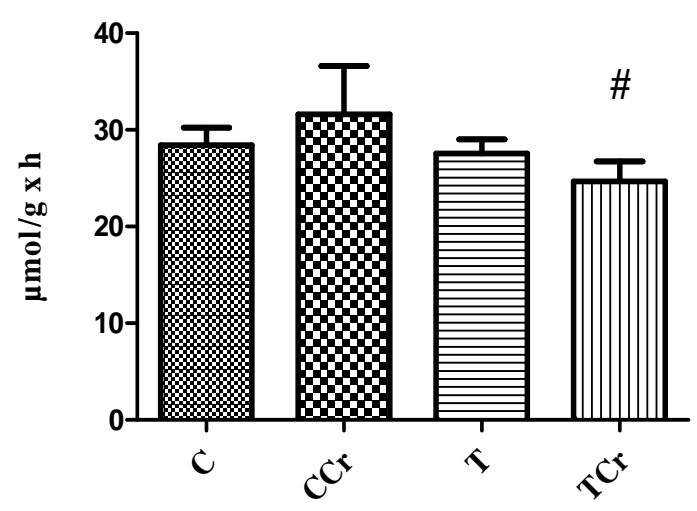

Glucose Oxidation

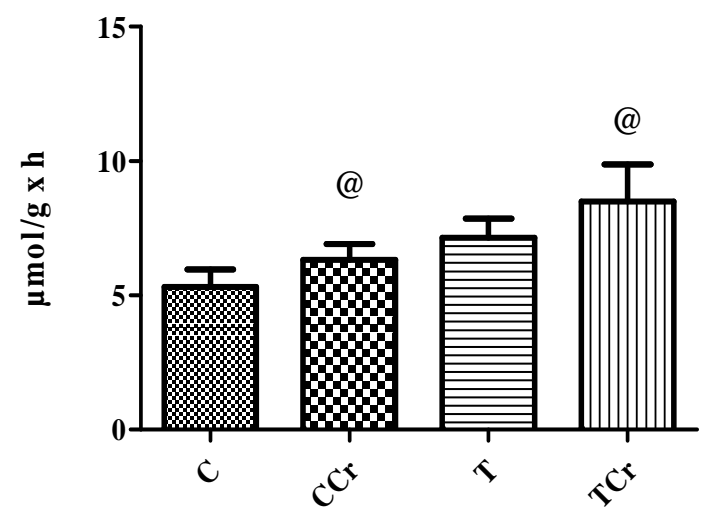

Glycogen Synthesis

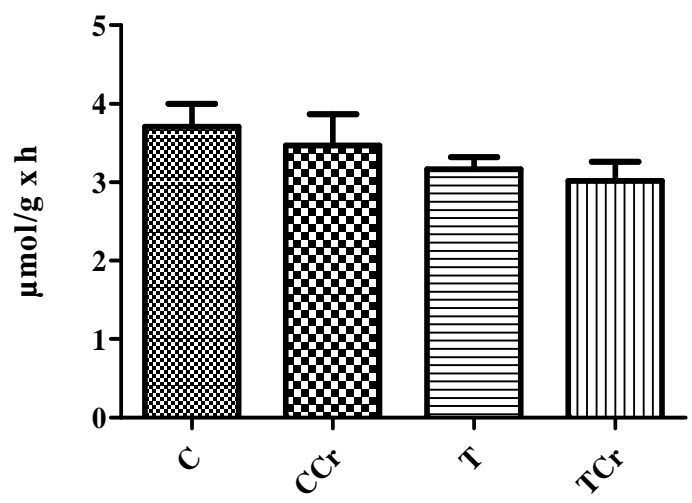

Glycogen Concentration

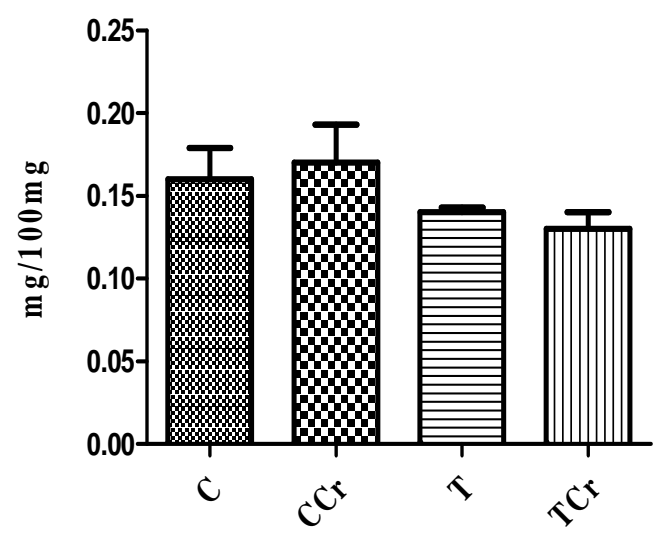

Figure 1. Uptake and glucose oxidation, glycogen synthesis, lactate production and glycogen concentration in isolated soleus muscles after euthanizing the animals. The results are expressed as the mean $\pm \mathrm{SD}$ of 10 muscle slices per group. $\mathrm{CrT}=\mathrm{Creatine} \mathrm{Trained}$; $\mathrm{T}=\mathrm{Trained}$; $\mathrm{CCr}=$ Control Creatine; $\mathrm{C}=\mathrm{Control}$ not Trained. \# different $\mathrm{CCr}$; @ different $\mathrm{T}$ and $\mathrm{C}$. 


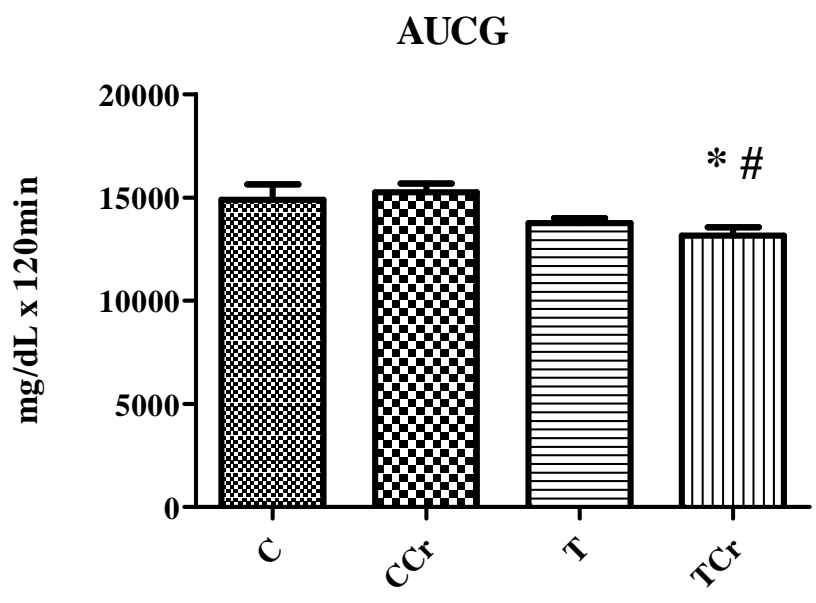

Figure 2. Area under the glucose curve during oral glucose tolerance test (OGTT) of the animals at the end of the experiment. The results are expressed as the mean $\pm \mathrm{SD}$ of 10 animals per group. $\mathrm{TCr}=$ Trained Creatine; $\mathrm{T}=$ Trained $; \mathrm{CCr}=$ Control Creatine; $\mathrm{C}=$ Control not Trained. $*$ different $\mathrm{C}$; \# different $\mathrm{CCr}$.

experiment. The animals in the $\mathrm{TCr}$ and $\mathrm{T}$ groups showed decreased body mass relative to the animals of the $\mathrm{C}$ and $\mathrm{CCr}$ groups. Creatine supplementation has been shown to produce contradictory effects on the change in body mass, as some authors have demonstrated an increase in body mass (Volek et al., 2004; Souza et al., 2006) and others have observed no change in body mass (Louis et al., 2003; Franco et al., 2007). Therefore, our hypothesis was that the observed body weight loss of the animals was not due to creatine supplementation but was solely a result of exercise. These results are in agreement with the literature reports of rats trained on treadmills using aerobic intensity protocols in which exercise reduced feed intake and, consequentially, resulted in weight loss (Bernardes et al., 2004; Silveira et al., 2008; Nery et al., 2011). Silveira et al. (2008) argued that, in response to physical training, there is an increase in lean mass, a decrease in fat mass, and a high uptake of fatty acids by the exercised tissue. Studies have shown that exercise may also increase brown adipose tissue (Bernardes et al., 2004) and thus contribute to an increase in thermogenesis and a reduction in total body weight. Another hypothesis is that physical exercise represents a form of stress and promotes the release of corticotrophin releasing hormone $(\mathrm{CRH})$ from the hypothalamus depending on the intensity of the stressor. Rivest and Richard (1990) showed anorexigenic effects induced by $\mathrm{CRH}$, which simulated the effects triggered by exercise. In this context, the aerobic exercises used in this study appear to represent a sufficient stressor stimulus capable of activating the hypothalamicpituitary adrenal axis.

In the analysis of the area under the food intake curves, no differences were not seen observed among the groups. Intake remained stable among the groups, but the area under the water intake curve showed increased consumption by the animals in the trained and creatine supplemented groups compared to the animals in the control groups. According to Hall (2011), plasma osmolality is the most potent stimulus for inducing thirst and, consequently, increasing the water intake of the animals. Poortmans and Francaux (2000) reported that creatine supplementation increased water intake, which in turn favored an increase in cellular hydration, increase in protein synthesis, decrease in proteolysis and development of a fat-free muscle mass.

As for the analysis of muscular metabolism indicators, glucose oxidation was increased in creatine-supplemented animals compared to non-supplemented animals. This effect may demonstrate a decrease in fatty acid oxidation, which is preferred at rest and during light exercise as a way to save glucose (Newsholme and Leech, 1983). In the TCr group, exercise allowed for a pathway redirection, favoring the incorporation of glucose into glycogen in proportions higher than those observed at rest and in the non-supplemented trained group. Corroborating the findings of Moura (2010), a study in which rats were fed a diet rich in fructose, the increase in the speed of incorporation of glucose may not be considered to be a response to glycogen depletion, given that the total glycogen concentrations in the muscle were not different among groups.

Another important result of the present study was that the isolated soleus muscle of the $\mathrm{TCr}$ animals showed a decrease in lactate production. Studies involving humans have reported that trained individuals show an increase in the transport capacity of lactate from muscle fibers to the bloodstream (Jacobs et al., 1986). These observations were also described by Oyono-Enguelle et al. (1990) in humans and by Gobatto et al. (2001) in rats. The increase in blood lactate concentration as well as the lower concentration of lactate in muscle was associated with the larger muscular efflux of lactate during acute exercise in well-conditioned individuals and animals. Ceddia et al. (2004) verified the influence of creatine supplementation on glucose metabolism and the formation of lactate. They observed that creatine supplementation increased the expression of creatine receptors (CT-1) and glucose receptors (GLUT-4). In turn, intramuscular glycogen content and $\mathrm{Cr}$ were also increased. Through an unknown mechanism, the high cellular concentrations of creatine and phosphocreatine (CP) attenuated the activity of lactate dehydrogenase (LDH) and decreased the formation of lactate.

The final result analyzed in this study was related to the area under the glucose curve during the oral glucose tolerance test (OGTT) of the animals at the end of the experiment. The trained animals supplemented with creatine had a lower OGTT compared to the control animals. Creatine supplementation combined with physical exercise improved the glucose tolerance of the animals at the end of the experiment. The animals trained and supplemented with creatine showed a lower OGTT compared to the animals in the control groups. As stated earlier, the administration of creatine affects glucose homeostasis. It has been demonstrated in vitro (Alsever et al., 2002) that creatine 
affects the metabolism of carbohydrates by directly stimulating insulin secretion from isolated pancreatic islets. This observation has been confirmed in vivo (Rooney et al., 2002) in studies investigating creatine supplementation in rats that observed the long-term effects of supplementation in glucose transport and glucose storage in skeletal muscle. These studies showed that, compared to control groups, high insulin secretion and changes in glucose homeostasis occur after eight weeks of supplementation. This result demonstrated that there is a relationship between the effects of prolonged creatine supplementation and its action in glucose metabolism, with increased pancreatic insulin secretion concomitant with hyperglycemia. It was observed that creatine use has an effect similar to that of sulfonylurea in glycemic control in type 2 diabetic patients (Rocic et al., 1999) and that using creatine may lead to similar results as observed in patients treated with metformin (Bajuk et al., 2001). According to the results Alves et al. (2012), this effect of creatine supplementation may be explained by the significant relationship between the increased expression of protein kinase alpha (AMPK-?) and the decreased level of glycated hemoglobin ( $\mathrm{Hb} 1 \mathrm{Ac}$ ), with a consequent increase in the translocation of glucose transporter 4 (GLUT4 ). Together, these results suggest that AMPK-? may play a role in facilitating the uptake of glucose induced by creatine in diabetic patients. AMPK-? signaling is activated by an increase in the AMP.

Based on these experimental findings, creatine supplementation, in conjunction with a program of physical activity, may improve glucose tolerance and reduce the development of insulin resistance as a consequence of the hypersecretion of this hormone.

In summary, we conclude that creatine supplementation, in conjunction with physical training, reduces body mass and improves the glycidic metabolism of animals. However, additional studies with larger sample sizes are needed to better elucidate these findings.

\section{References}

Alsever, R.N., Georg, R.H., \& Sussman, K.E. (1970). Stimulation of insulin secretion by guanidinoacetic acid and other guanidine derivatives. Endocrinology, 86, 332-6.

Alves, C.R.R., Ferreira, J.C., Siqueira-Filho, M.A., Carvalho, C.R., Lancha Jr, A.H., \& Gualano, B. (2012). Creatine-induced glucose uptake in type 2 diabetes: a role for AMPK-a? Amino Acids, 43, 1803-1807.

Araújo, M.B., \& Mello, M.A.R. (2009). Exercício, estresse oxidativo e suplementação com creatina. Revista Brasileira de Nutrição Esportiva, 3 (15), 264-272.

Araújo, M.B., Moura, L.P., Ribeiro, C., Dalia, R.A., Voltarelli, F.A., \& Mello, M.A.R. (2011), Oxidative stress in the liver of exercised rats supplemented with creatine. International Journal of Nutrition and Metabolism, 3 (5), 58-64.

Bemben, M.G. \& Lamont, H.S. (2005). Creatine supplementation and exercise performance: recent findings. Sports Medicine, $35,107-125$.
Bernardes, D., Manzone, M.S.J., Souza, C.P., Tenorio, N., \& Damaso, A.R. (2004). Efeitos da dieta hiperlipidica e do treinamento de natação sobre o metabolismo de recuperação ao exercício em ratos. Revista Brasileira de Educação Física e Esportes, 18, 191-200.

Ceddia, R.B. \& Sweeney, G. (2004). Creatine supplementation increases glucose oxidation and AMPK phosphorylation and reduces lactate production in L6 rat skeletal muscle cells. The Journal of Physiololy, 555, 409-21.

Costallat, B.L., Miglioli, L., Silva, P.A.C., Novo, N.F., \& Duarte, J.L.G. (2007). Resistência à insulina com a suplementação de creatina em animais de experimentação. Revista Brasileira de Medicina do Esporte, 13 (1), 22-26.

Deminice, R., Portari, G.V., Vannucchi, H., \& Jordao, A.A. (2009). Effects of creatine supplementation on homocysteine levels and lipid peroxidation in rats. British Journal of Nutrition, 102 (1), 110-116.

Dubois, M., Gilles, K.A., Hamilton, J.K., Rebers, P.A., \& Smith, F. (1956). Colorimetric method for determination of sugar and related substances. Analytical Chemistry, 28, 350-356.

Franco, F.S.C., Natali, A.J., Costa, N.M.B., Lunz, W., Gomes, G.J., Carneiro Junior, M.A., \& Oliveira, T.T. (2007). Efeitos da suplementação de creatina e do treinamento de potência sobre a performance e a massa corporal magra de ratos. Revista Brasileira Medicina Esporte, 13 (5), 207-302.

Freire, T.O., Gualano, B., Leme, M.D., Polacow, V.O., \& Lancha Jr, A.H. (2008). Efeitos da Suplementação de Creatina na Captação de Glicose em Ratos Submetidos ao Exercício Físico. Revista Brasileira de Medicina do Esporte, 14 (5), 431-435.

Gobatto, C.A., Mello, M.A., Sibuya, C.Y., Azevedo, J.R., Santos, L.A., \& Kokubun, E. (2001). Maximal lactate steady state in rats submitted to swimming exercise. Comparative Biochemistry and Physiology - Part A, 130, 21-27.

Gualano, B., Novaes, R.B., Artioli, G.G., Freire, T.O., Coelho, D.F., Scagliusi, F.B., Rogeri, P.S., Roschel, H., Ugrinowitsch, C., \& Lancha Junior, A.H (2008). Effects of creatine supplementation on glucose tolerance and insulin sensitivity in sedentary healthy males undergoing aerobic training. Amino Acids, 34 (2), 245-50.

Herbert, V., Lau, K.S., Gottlieb, C.W., \& Bleicher, S.J. (1965). Coated Charcoals immunoassay of insulin. The Journal of Clinical Endocrinology \& Metabolism, 25, 1375-84.

Hespel, P., Op'T Eijnde, B., \& Van Leemputte, M. (2002). Opposite actions of caffeine and creatine on muscle relaxation time in humans. Journal of Applied Physiology, 92, 513-518.

Hall, J.E. (2011). Tratado de Fisiologia Médica (12 ed.). Rio de Janeiro: Elsevier.

Hill, A.V., Long, C.N.H., \& Lupton, H. (1924). Muscular exercise, lactic acid, and the supply and utilization of oxygen: parts IVVI. Proceedings the Royal Society B, 97, 84-138.

Hoffman, J., Ratamess, N., Kang, J., Mangine, G., Faigenbaum, A., \& Stout, J. (2006). Effect of creatine supplementation on performance and endocrine responses in strength/power athletes. International Journal of Sport Nutrition and Exercise Metabolism, 16, 430-446.

Hultman, E., Soderlund, K., Timmons, J., Cederblad, G., \& Greenhaff, P. (1996). Muscle creatine loading in man. Journal of Applied Physiology, 81, 232-237.

Jacobs, I. (1986). Blood lactate. Implications for training and sports performance. Medicine and Science in Sports and Exercise, 3, 10-25.

Khanna, G.L. \& Manna, I. (2005). Supplementary effect of carbohydrate-electrolyte drink on sports performance, lactate removal \& cardiovascular response of athletes. The Indian 
Journal of Medical Research, 121, 665-9.

Louis, M., Poortmans, J.R., Francaux, M., Hultman, E., Berré, J., Boisseau, N., Young, V.R., Smith, K., Meier-Augenstein, W., Babraj, J.A., Waddell T., \& Rennie, M.J. (2003). Creatine supplementation has no effect on human muscle protein turnover at rest in the postabsorptive or fed states. American Journal of Physiology - Endocrinology and Metabolism, 284, E764-E770.

Manchado, F.B., Gobatto, C.A., Contarteze, R.V.L., Papoti, M., \& Mello, M.A.R. (2005). Maximal lactate steady in running rats. The Journal of Exercise Physiologyonline, 8, 29-35.

Mathews, J.N.S., Altman, D.G., Campbell, M.J., \& Royston, P. (1990). Analysis of serial measurements in medical research. British Medical Journal, 27, 230-235.

Moura, R.F. (2010). Exercício físico na prevenção e no tratamento da síndrome metabólica: um modelo experimental com ratos. Tese de Doutorado. Universidade Estadual Paulista. Rio Claro.

Nery, C.S., Pinheiro, I.L., Muniz, G.S., Vasconcelos, D.A.A., Franca, S.P., \& Nascimento, E. (2011). Medidas murinometricas e eficiência alimentar em ratos provenientes de ninhadas reduzidas na lactação e submetidos ou não ao exercício de natação. Revista Brasileira de Medicina do Esporte, 17(1), 4955.

Newman, J,E., Hargreaves, M., Garnham, A., \& Snow, R.J. (2003). Effect of creatine ingestion on glucose tolerance and insulin sensitivity in men. Medicine Science Sports Exercise, 35, 6974.

Newsholme, E.A. \& Leech, A.R. (1983). Biochemistry for the medical sciences. New York: John Wiley \& Sons.

Nogueira, D. M. (1990). Métodos de bioquímica clínica. São Paulo: Pancast.153-168.

Nunes, W.M. \& Mello, M.A.R. (2005). Metabolism in rats submitted to skeletal muscle denervation. Brazilian Archives of Biology and Technology, 48 (4), 541-548.

Odoom, J.E.G.J. \& Radda, G.K. (1996). The regulation of total content in a myoblast cell line. Molecular and Cellular Biochemistry, 158, 179-188.

Op'T Eijnde, B., Urso, B., Richter, E.A., Greenhaff, P.L., \& Hespel, P. (2001). Effect of oral creatine supplementation on human muscle GLUT-4 protein content after immobilization. Diabetes, 50, 18-23.

Oyono-Enguelle, S., Marbach, J., Heitz, A., Ott, C., Gartner, M., Pape, A., Vollmer, J.C., \& Freund, H. (1990). Lactate removal ability and grated exercise in humans. Journal of Applied Physiology, 68, 905-911.

Poortmans, J.R. \& Francaux, M. (2000). Long-term oral creatine supplements does not impair renal function in healthy athletes. Medicine Science Sports Exercise, 31 (8), 379-85.

Reeves, P.G., Nielsen, F.H., \& Fahey, G.C. (1993). AIN-93 purified diets for laboratory rodents: final report of the American Institute of Nutrition ad hoc writing committee on the reformulation of the AIN-76A rodent diet. Journal of Nutrition, 23 (11), 1939-1951.

Rooney, K., Bryson, J., Phuyal, J., Denyer, G., Caterson, I., \& Thompson, C. (2002). Creatine supplementation alters insulin secretion and glucose homeostasis in vivo. Metabolism, 51, $518-22$.

Rivest, S. \& Richard, D. (1990). Hypothalamic paraventricular nucleus lesions do not prevent anorectic effect of exercise in male rats. American Journal of Physiology, 259, 579-584.

Sjörgreen, B., Norden, S.K., Jold, T., Holmgren, H., \& Wollerstron, J. (1938). Bertrag zur kenthis des le berrhythmik. Pflügers Arch Gesamte Physiology, 240-247.
Silveira, L.R., Fiamoncini, J., Hirabara, S.M., Procopio, J., \& Cambiaghi, T.D. (2008). Updating the effects of fatty acids on skeletal muscle. Journal of Cell Physiology, 217, 1-12.

Souza, R.A., dos Santos, R.M., Osório, R.A.L.Z., Cogo, J.C., Prianti Júnior, A.C.G., Martins, R.A.B.L., \& Ribeiro, W. (2006). Influência da suplementação aguda e crônica de creatina sobre as concentrações sanguíneas de glicose e lactato de ratos Wistar. Revista Brasileira de Medicina do Esporte, 12 (6), 361-365.

Vandenberghe, K., Goris, M., Van Hecke, P., Van Leemputte, M., Vangerven, L., \& Hespel, P. (1997). Long-term creatine intake is beneficial to muscle performance during resistance training. Journal of Applied Physiology, 83, 2055-2063.

Volek, J.S. \& Rawson, E.S. (2004). Scientific basis and practical aspects of creatine supplementation for athletes. Nutrition, 20, 609-14

Williams, M.H., Kreider, R., \& Branch, J.D. (2000). "Creatina.” São Paulo, Ed Manole.

Young, J.C. \& Young, R.E. (2002). The effect of creatine supplementation on glucose uptake in rat skeletal muscle. Life Science, 71, 1731-7.

\section{Authors' note}

\section{Correspondence to:}

Dr. Michel Barbosa de Araújo

Travessa Maracanã, 84, Vila Tibério, 14050-429, Ribeirão Preto, SP, Brazil

Phone: +55 19991005156,

E-mail:mbujo@ig.com.br

\section{Acknowledgements}

This study was supported by Fundação de Amparo à Pesquisa do Estado de São Paulo, Brazil Process \# 2009/52063-0).

\section{Declaration of Conflict of Interests}

The authors declared no conflicts of interest exist with respect to the research, authorship, and/or publication of this article.

Manuscript received on October 16, 2012

Manuscript accepted on September 16, 2013

Motriz. Journal of Physical Education. UNESP, Rio Claro, SP Brazil, eISSN: 1980-6574, is licenced under a Creative Commons License, Version 3.0. 